\title{
PENGEMBANGAN MEDIA PEMBELAJARAN E-VOCATIONAL DENGAN MATERI MENGGAMBAR POTONGAN LANJUTAN UNTUK MATA KULIAH PROGRAM CAD 2D
}

\author{
Muhammad Rizqi Ganis Pareta1,Abdul Haris Setiawan² ,Sukatiman² \\ Email: rizqiganis.p1025@gmail.com
}

\begin{abstract}
Abstrak: Tujuan penelitian ini adalah untuk: (1) Menghasilkan media pembelajaran E-Vocational dengan materi menggambar potongan lanjutan untuk mata kuliah program CAD 2D. (2) Mengetahui tingkat kelayakan Media Pembelajaran EVocational dengan materi menggambar potongan lanjutan untuk mata kuliah program CAD 2D.

Penelitian ini menggunakan metode penelitian riset dan pengembangan, dengan melakukan pengembangan media pembelajaran E-Vocational. Prosedur pengembangan media pembelajaran dilakukan melalui: (1) Tahap studi pendahuluan dilakukan dengan studi literatur dan studi lapangan/observasi. (2)Tahap pengembangan dengan melakukan pengkajian materi, penyusunan desain model yang dibagi menjadi 6 bagian diantaranya: penyusunan draf materi dan dasar-dasar e-learning, proses pembuatan media pembelajaran E-Vocational, pembuatan materi, pembuatan editing video pembelajaran, upload materi dan video pembelajaran pada E-Vocational, media pembelajaran EVocational. Selanjutnya melakukan validasi penilaia kepada para ahli / pakar materi, media dan pembelajaran untuk menilai kelayakan media pembelajaran yang dibuat. Selanjutnya melakukan uji coba terbatsa dengan 3 mahasiswa yang mengambil mata kuliah program CAD 2D dan uji coba luas kepada 30 mahasiswa PTB FKIP UNS tahun angkatan 2015. (3) Tahap evaluasi merupakan tahap akhir dari proses pengembangan terkait model final media pembelajaran E-Vocational dengan materi menggambar potongan lanjutan untuk mata kuliah program CAD 2D.

Hasil penelitian yang pertama berupa prosedur pengembangan E-Vocational yang meliputi Studi Literatur, Pengkajian Materi, Draft Desain Model, Validasi Desain, Uji Coba Kelompok Kecil, Evaluasi dan Perbaikan, Uji Coba Kelompok Luas, Evaluasi, Perbaikan, dan Model Final. Selanjutnya yang kedua di peroleh tingkat kelayakan berdasarkan penilaian ahli materi menyatakan bahwa media pembelajaran E-Vocational sangat layak digunakan dengan persentase sebesar $85 \%$. Penelitian dari penilaian ahli media menyatakan bahwa media pembelajaran E-Vocational sangat layak digunakan dengan persentase sebesar 93\%. Penelitian dari penilaian ahli pembelajaran menyatakan bahwa media pembelajaran E-Vocational layak digunakan dengan persentase sebesar $77 \%$ sedangkan uji coba terbatas hasil yang diperoleh sebesar $92 \%$ menyatakan bahwa media pembelajaran yang dirancang sangat layak kemudian pada uji coba luas menyatakan dengan persentase $84 \%$ bahwa media pembelajaran termasuk kategori sangat layak
\end{abstract}

Kata Kunci : Media, Pembelajaran, Program CAD 2D, E-Vocational

${ }^{1}$ Mahasiswa Program Studi Pendidikan Teknik Bangunan FKIP UNS

2 Pengajar Program Studi Pendidikan Teknik Bangunan FKIP UNS 


\title{
THE DEVELOPMENT OF E-VOCATIONAL LEARNING MEDIA WITH THE MATERIAL OF DRA WING ADVANCED CUTTING FOR THE 2D CAD PROGRAM COURSE
}

\author{
Muhammad Rizqi Ganis Pareta1, Abdul Haris Setiawan², Sukatiman² \\ Email: rizqiganis.p1025@gmail.com
}

\begin{abstract}
The objectives of this research are to: (1) Produce the E-Vocational learning media with the material of drawing advanced cutting for the $2 D C A D$ program course. (2) Know the feasibility level of E-Vocational Learning Media with the material of drawing advanced cutting for the $2 D C A D$ program course.

The methodology of this research was research and development, by performing the development of E-Vocational learning media. The procedures of the development of learning media were performed through: (1) The introduction study was conducted by literature study and field study/observation. (2) The development stage was created by conducting the material review, arranging the model design which was divided into 6 parts which were: compiling material draft and the basic of e-learning, creating the EVocational media learning, making the material, creating the editing of learning video, uploading the material and the E-Vocational learning video, E-Vocational learning media. Furthermore, conducting the validation score to the experts/material experts, media and learning to assess the feasibility of the learning media. The next was conducting limited trials with 3 students taking $2 D$ CAD program course and extensive trials to the 30 students of Building Engineering Education in the Faculty of Teacher Training and Education UNS year 2015. (3) The evaluation stage was the last stage of the process of the development related to the final model E-Vocational learning media with the material of drawing advanced cutting for the $2 D C A D$ program course.

The results of the first research were procedures for E-Vocational development which includ Literature Study, Material Assessment, Model Design Draft, Design Validation, Small Group Trial, Evaluation and Improvement, Broad Group Trials, Evaluation, Improvement, and Final Model. Then the second level of feasibility was obtained based on the assessment of material experts stating that the E-Vocational learning media was very suitable to use with a percentage of $85 \%$. Research from the assessment of media experts stated that E-Vocational learning media was very suitable to use with a percentage of 93\%. Research from the assessment of learning experts stated that EVocational learning media was feasible to use with a percentage of $77 \%$ while the limited trial results obtained by $92 \%$ stated that the instructional media that was designed was very feasible then in extensive trials stated with a percentage of $84 \%$ that the learning media including a very decent category
\end{abstract}

Keywords: Media, Learning, 2D CAD Program, E-Vocational

${ }^{1}$ Student of Building Engineering of Education FKIP UNS

${ }^{2}$ Lecturer of Building Engineering of Education FKIP UNS 


\section{PENDAHULUAN}

Perkembangan teknologi di era globalisasi ini semakin pesat. Perkembangan tersebut mempengaruhi beberapa aspek dalam kehidupan. Teknologi juga mampu mengubah pandangan seseorang dalam mencari dan mendapatkan informasi melalui sumber yang lengkap dan tak terbatas yaitu media internet. Bidang pendidikan merupakan salah satu bidang yang mendapat pengaruh dari adanya perkembangan teknologi, saat ini pendidikan tidak terlepas dari penggunaan teknologi dalam proses pembelajaran

Mewujudkan masyarakat cerdas dan terampil di era globalisasi sekarang perlu adanya sistem pendidikan yang maju. Sistem ini harus bisa menjamin perluasan harapan pendidikan untuk menghadang persaingan dunia yang mana perlu dilakukan inovasi pendidikan secara terorganisasi dan berkelanjutan dengan pemanfaatan teknologi pembelajaran. Penggunaan teknologi informasi menciptakan pembelajaran lebih menarik, efektif, dan inovatif. Hal ini bertujuan menerapkan pelaksanaan pembelajaran efektif seperti yang termuat dalam isi Permendikbud No. 65 Tahun 2013 tentang penggunaan teknologi informasi untuk meningkatkan efisiensi dan efektivitas pembelajaran. Dengan demikian, pembelajaran dengan terintegrasi teknologi informasi sangat diperlukan demi tercapainya peningkatan mutu dan kualitas belajar mengajar. Salah satu bentuk penggabungan teknologi informasi dan komunikasi dalam bidang pendidikan yaitu E-learning atau elektrronik learning. E-learning tidak hanya menjadi ketertarikan di kalangan akademik, tapi juga di manfaatkan di kalangan profesional, perusahaan, maupun kalangan industry.

Dari pemaparan perkembangan media informasi dankomunikasi di dunia pendidikan diatas terdapat permasalahan pada mata kuliah program CAD 2D belum memanfaatkan pengembangan teknologi secara optimal hal ini ditunjukkan dari pembelajaran yang masih dilakukan dengan tatap muka dikelas saja sehingga hal ini akan membuat mahasiswa hanya bergantung materi yang dijelaskan dosen di kelas. Selain itu belum tersedia media pembelajaran yang bisa mendukung mahasiswa untuk belajar sendiri dan membantu komunikasi antara dosen dengan mahasiswa jika ada mahasiswa yang memiliki kesulitan belajar dalam pemahaman materi di luar jam kelas. Ditambah dengan jadwal ruangan laboratorium komputer yang padat sebagai ruang kelas mata kuliah program CAD 2D, sehingga harus berebut dengan kelas dan program studi yang lain. Masalah ini didapatkan setelah melakukan observasi secara diskusi dengan dosen pengampu dan mahasiswa yang telah mengikuti mata kuliah program CAD 2D. Hasilnya $80 \%$ dari mahasiswa yang mengikuti diskusi bersama dalam observasi menyatakan permasalahan tersebut

Program CAD 2D merupakan mata kuliah yang ada pada program studi Pendidikan Teknik Bangunan (PTB) di Fakultas Keguruan Dan Ilmu Pendidikan Universitas Sebelas Maret 
yang bertujuan: (1) Menghasilkan lulusan yang berkarakter kuat, cerdas, dan kompeten yang siap menjadi pengajar di bidang pendidikan teknik bangunan yang profesional. (2) Menghasilkan temuan di bidang pendidikan teknik bangunan, dan menuangkannya dalam bentuk artikel ilmiah yang siap dipublikasikan. (3) Menghasilkan karya-karya dedikasi kepada masyarakat yang mampu menyelesaikan permasalahan praktis pada aspek pendidikan teknik bangunan.

Program CAD 2D adalah mata kuliah yang mengkaji tentang cara menggambar berbagai macam gambar khususnya bangunan menggunakan aplikasi komputer AutoCad. Sesuai dengan namanya gambar bangunan masih pada gambar 2 dimensi yang nantinya akan ada Program CAD 3D di semester berikutnya sebagai mata kuliah berkelanjutan. Mahasiswa setelah lulus pada mata kuliah ini di harapkan mampu menggambar bangunan 2 dimensi seperti rumah dan bangunan gedung lainya (lebih dari 2 lantai) dengan aplikasi Autocad. Pada mata kuliah ini pertama mahasiswa akan di kenalkan dengan aplikasi perangkat lunak AutoCad, cara menggambar bangunan, ketentuanketentuan dalam menggambar bangunan, sampai pada proses mencetak hasil gambar yang telah di gambar pada aplikasi AutoCad.

Pada mata kuliah Program CAD 2D akan menunjang para mahasiswa di dunia kerja terutama pada materi menggambar potongan lanjutan. Menggambar potongan lanjutan adalah kelajutan dari gambar bestek (denah, tampak, potongan) yang berisi tentang gambar detail seperti detail atap, kudakuda, pondasi dan lain-lain. Gambar tersebut biasanya di buat oleh arsitek yang nanti di kembangkan oleh drafter sebagai gambar kerja shop drawing. Gambar shop drawing di gunakan sebagai acuan pekerjaan bangunan dalam suatu proyek. Dalam dunia pendidikan mata kuliah ini bermanfaat sebagai bahan ajar seorang guru gambar bagunan untuk mengajari siswa sekolah menengah kejuruan bangunan tentang bagaimana menggambar detail suatu bangunan yang dapat di pahami oleh para pekerja bangunan.

Seperti yang sudah di jelaskan sebelumnya bahwa pembelajaran dengan menggunakan internet merupakan jalan yang baik dan akan semakin berkembang seiring perkembangan teknologi, maka diperlukan pengembangan media pembelajaran $E$ learning yang mengikuti alur perkembangan jaman dan dibutuhkan oleh mahasiswa dan dosen seperti yang ditegaskan oleh Indriana (2011: 15) bahwa mendia merupakan alat bantu yang sangat bermanfaat bagi para siswa dan pendidik dalam proses belajar dan mengajar. Hal ini seperti yang sedang dilakukan Mahasiswa PTB angkatan 2014 termasuk peneliti yaitu mengembangkan media pembelajaran yang berbasis media informasi online, selain itu bisa digunakan dimanapun dan kapanpun selama masih ada akses internet. E-learning secara khusus di kembangkan untuk dosen dan mahasiswa yang mudah dan menarik karena dalam pemberian materi dapat 
dilakukan tanpa harus adanya tatap muka di kelas antara dosen dengan mahasiswa tidak terbatas ruang dan waktu. Memperkecil mobilitas antara mahasiswa dan dosen sehingga memperkecil waktu yang terbuang. Membuat jadwal kelas dengan media komunikasi, membuat suatu ruang kelas, dan melakukan pembelajaran hanya dengan via online. Dengan media pembelajaran yang interakif sebagaimana mahasiswa aktif dalam berpartisipasi dalam proses pembelajaran. Mahasiswa juga dapat berkomunikasi langsung dengan teks, gambar, suara, maupun video sehingga di dapat suasana belajar yang efektif.

Penelitian ini bertujuan untuk mengetahui prosedur ekspansi Media Pembelajaran E-Vocational dengan materi menggambar potongan lanjutan untuk mata kuliah program CAD 2D dan Untuk mengetahui tingkat kelayakan Media Pembelajaran E-Vocational dengan materi menggambar potongan lanjutan untuk mata kuliah program CAD 2D.

Menurut Indriana (2011: 16) Pengertian media pembelajaran adalah semua bahan dan alat fisik yang mungkin digunakan untuk mengimplementasikan pengajaran dan menfasilitasi prestasi siswa terhadap sasaran atau tujuan pengajaran. Menurut Aqib (2013:50) media pembelajaran adalah segala sesuatu yang dapat digunakan untuk menyalurkan pesan dan merangsang terjadinya proses belajar pada si pembelajar (siswa). Sedangkan menurut Sanaky (2015: 4) bahwa media pembelajaran adalah sarana atau alat bantu pendidikan yang dapat digunakan sebagai perantara dalam proses pembelajaran untuk mempertinggi efektifitas dan efisiensi dalam mencapai tujuan pengajaran.

Dari penjelasan ahli tersebut dapat ditarik kesimpulan bahwa media pembelajaran adalah suatu alat yang berguna untuk penyampaian pesan pada saat proses pembelajaran dari guru kepada siswa secara efektif dan efisien dalam mencapai tujuan pengajaran.

Menurut Sjukur (2012:

menjelaskan bahwa Blended learning adalah kombinasi pembelajaran tradisional dan lingkungan pembelajaran elektronik. Blended learning menggabungkan aspek pembelajaran berbasis web/ internet, streaming video, komunikasi audio synchronous dan asynchronous dengan pembelajaran tradisional "tatap muka".

Blended learning is the most logical and natural evolution of our learning agenda. It suggests an elegant solution to the challenges of tailoring learning and development to the needs of individuals. It represents an opportunity to integrate the innovative and technological advances offered by online learning with the interaction and participation offered in the best of traditional learning. (Thorne, 2003: 16).

Thorne (2003: 16) menjelaskan bahwa blended learning merupakan evolusi yang paling logis dalam pembelajaran.

Berdasarkan pengertian tersebut, dapat disimpulkan bahwa Blended Learning adalah kombinasi antara pembelajaran konvensional (tatap muka 
dalam kelas) dengan pembelajaran online (daring)

E-Vocational merupakan pengembangan model dari platform efront, dengan tujuan untuk mempermudah mahasiswa Pendidikan Teknik Bangunan dalam belajar. Untuk menambah wawasan dan referensi belajar mahasiswa serta dosen mampu beradaptasi dengan perkembangan teknologi yang ada saat ini maka tercipta ide untuk membuat E-Vocational.

\section{METODE PENELITIAN}

Metode dalam penelitian ini adalah metode penelitian dan pengembangan atau Research and Development. metode penelitian ini adalah metode penelitian yang berfungsi untuk menciptakan produk tertentu dan menilai kefektifan produk tersebut. Pada penelitian ini yang akan dikembangkan adalah pengembangan media pembelajaran E-Vocational dengan materi menggambar potongan lanjutan untuk mata kuliah program CAD 2D. Langkah-langkah penelitian ini menurut Sugiono (2017: 409) yang dijelaskan pada gambar 1

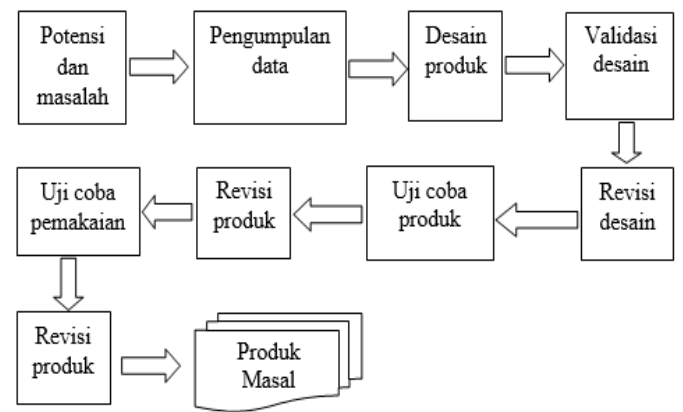

Gambar 1. Langkah-langkah Metode Research and Development Sumber: Sugiyono (2017: 409).

Rencana kegiatan penelitian ini hanya sampai pada uji kelayakan $E$ -
Vocational sebagai media pembelajaran pada materi menggambar potongan lanjutan untuk mata kuliah program CAD 2D dengan di lanjutkan evaluasi model final. Dengan demikian, peneliti melakukan penyederhanaan metode penelitian menjadi tiga bagian diantaranya studi pendahuluan, pengembangan, dan evaluasi.

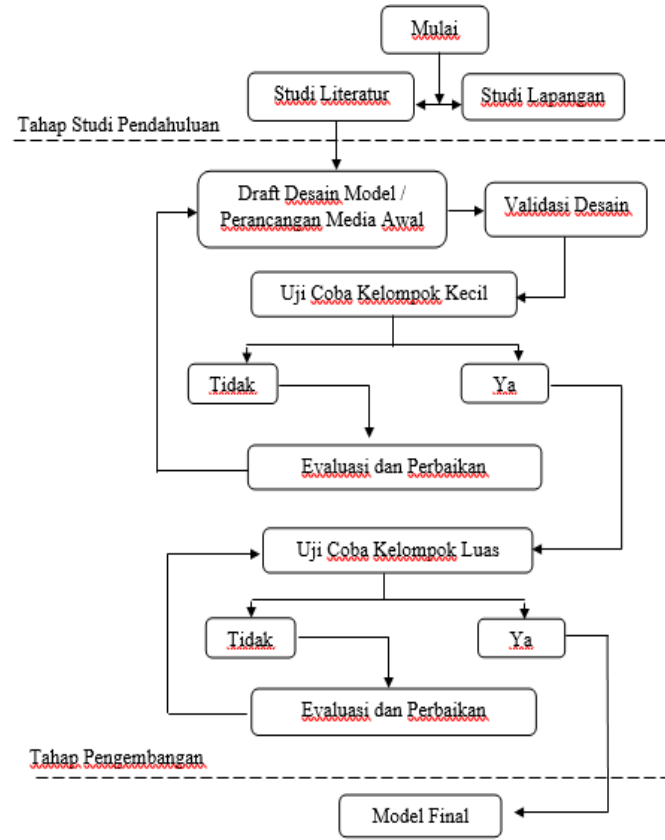

Gambar 2. Alur Prosedur E-Vocational sebagai media pembelajaran

Penelitian ini menggunakan instrumen berupa lembar penelitian kelayakan media pembelajaran $E$ Vocational dengan materi menggambar potongan lanjutan untuk mata kuliah program CAD 2D untuk validator yang meliputi: penilaian ahli materi, penilaian ahli media, dan penilaian ahli pembelajaran.

Untuk mengukur tingkat kelayakan media pembelajaran yang telah dibuat, maka digunakan skala pengukuran menggunakan skala likert. Skala Likert berguna untuk menilai sikap, opini, dan persepsi seseorang atau beberapa orang tentang kejadian 
tertentu. Dengan variabel yang akan dinilai, dijabarkan menjadi indikator variabel. Selanjutnya indikator variabel dijadikan sebagai titik tolak untuk membuat butir-butir instrument yang dapat berupa pernyataan atau pertanyaan. Jawaban setiap butir instrumen yang menggunakan skala likert mempunyai tingkatan dari sangat positif sampai sangat negatif.

Suatu instrument harus di katakana reliabel atau dapat konsisten dari waktu ke waktu. Maka jawaban yang telah terkumpul di lakukan uji reliabilitas menggunakan rumus alpha Cronbach yang di aplikasikan pada program excel atau spss. Berikut adalah rumus dari alpha Cronbach pada gambar 3. :

$$
r_{11}=\left(\frac{n}{n-1}\right)\left(1-\frac{\sum \sigma_{t}^{2}}{\sigma_{t}^{2}}\right)
$$

Keterangan :

$$
\begin{array}{ll}
\mathrm{r} 11 & =\text { reliabilitas yang dicari } \\
\mathrm{n} & =\text { Jumlah item pertanyaan yang di uji } \\
\Sigma \sigma \mathrm{t} 2 & =\text { Jumlah varians skor tiap-tiap item } \\
\sigma \mathrm{t} 2 & =\text { vrians total }
\end{array}
$$

\section{Gambar 3. Rumus alpha conbrach}

Setelah diperoleh hasil pengukuran dari tabulasi skor maka perhitungan skor dapat diadopsi dari skala likert berdasarkan pendapat Sugiyono (2017: 136) adalah sebagai berikut:

Tabel 1. Kriteria Penilaian Kelayakan

\begin{tabular}{lc}
\hline Kategori Penilaian & Skor \\
\hline Sangat Layak & 5 \\
Layak & 4 \\
Cukup Layak & 3 \\
Tidak Layak & 2 \\
Sangat Tidak Layak & 1 \\
\hline
\end{tabular}

Tabel 2. Interprestasi Kriteria Hasil Penelitian

\begin{tabular}{ll}
\hline Kategori Penelitian & \multicolumn{1}{c}{ Interpretasi } \\
\hline Sangat Layak & $\begin{array}{l}\text { Ahli media, ahli materi, ahli pembelajaran, dan pengguna } \\
\text { (mahasiswa) menyatakan bahwa media pembelajaran } E \text { - }\end{array}$ \\
& vocational sangat layak digunakan sebagai media \\
& pembelajaran \\
Layak & Ahli media, ahli materi, ahli pembelajaran, dan pengguna \\
& (mahasiswa) menyatakan bahwa media pembelajaran $E$ - \\
& vocational layak digunakan sebagai media pembelajaran \\
Cukup Layak & Ahli media, ahli materi, ahli pembelajaran, dan pengguna \\
& (mahasiswa) menyatakan bahwa media pembelajaran $E$ - \\
& vocational cukup layak digunakan sebagai media \\
& pembelajaran \\
Tidak Layak & Ahli media, ahli materi, ahli pembelajaran, dan pengguna \\
& (mahasiswa) menyatakan bahwa media pembelajaran $E$ - \\
& vocational tidak layak digunakan sebagai media \\
& pembelajaran \\
Sangat Tidak Layak & Ahli media, ahli materi, ahli pembelajaran, dan pengguna \\
& (mahasiswa) menyatakan bahwa media pembelajaran $E$ - \\
& vocational sangat tidak layak digunakan sebagai media \\
& pembelajaran
\end{tabular}

Perhitungan persentase dilaksanakan dengan cara membandingkan frekuensi yang didapat dengan frekuensi yang diinginkan. Persentase dihitung dengan menerapkan rumus yaitu:

\section{Persentase $=$ Frekuensi yang diperoleh $x \quad 100 \%$ Frekuensi yang diharapkan}

\section{HASIL DAN PEMBAHASAN}

Penelitian ini dilakukan dengan 3 tahapan utama yaitu:

1. Tahap Studi Pendahuluan

Studi literatur dilaksanakan dengan menggali referensi maupun rujukan berkaitan dengan mata kuliah program CAD 2D. Sedangkan studi lapangan adalah melakukan pengamatan di lapangan dengan mencari informasi, mengkaji permasalahan dan mengidentifikasi masalah dari hasil observasi yang telah dilakukan. Dari observasi yang dilakukan didapatkan 
hasil bahwa penggunaan media $e$ learning dalam pembelajaran belum maksimal, terbukti pada saat pembelajaran yang dilakukan menggunakan LCD yang membuat mahasiswa memfokuskan pada arahan LCD dan pengarahan dosen saja selain itu pembelajaran juga hanya dilakukan dengan tatap muka saja sehingga interaksi antara dosen dan mahasiswa masih kurang.

2. Tahap Pengembangan

Pada tahap pengembangan terdapat beberapa kegiatan diantaranya:

a. Pengkajian materi

Pengkajian materi di lakukan dengan arahan dari dosen pengampu mata kuliah program CAD 2D yang bersumber pada RPS.

b. Penyusunan Desain Model

1) Penyusunan draft materi dan dasar-dasar e-learning

Penyusunan draft materi pada mata kuliah program CAD 2D mengacu pada silabus yang berlaku sesuai dengan kurikulum yang ada. Sedangkan dasar e-learning yang di gunakan adalah menggunakan website yang berdasar pada aplikasi eFront.

2) Proses pembuatan media pembelajaran E-Vocational.

3) Pembuatan materi

Pada tahap ini peneliti menyiapkan materi didapatkan dari dosen pengampu, buku dan modul yang relevan.

4) Pembuatan dan Editing video pembelajaran

Tahap selanjutnya adalah pembuatan video pembelajaran diawali dengan membuat gambar menggunakan apikasi AutoCad yang direkam dengan menggunakan aplikasi Bandicam Tahap editing video dilakukan ketika serangkaian pengambilan video telah selesai.

5) Upload materi dan video pembelajaran pada E-Vocational

Proses penguploadan adalah tahap dimana memasukan dokumen materi dan video pembelajaran kedalam media pembelajaran E-Vocational yang akhirnya menjadi penyajian media pembelajaran yang utuh.

6) Media pembelajaran $E$ Vocational

Pada tahap ini media pembelajaran E-Vocational telah selesai di buat oleh peneliti. Didalamnya terdapat fitur-fitur untuk menunjang media pembelajaran. Media pembelajaran E-Vocational sudah dapat di akses oleh pengguna atau mahasiswa dengan mengakses www.evocatonal.co.id. Seperti yang terlihat pada gambar berikut ini:

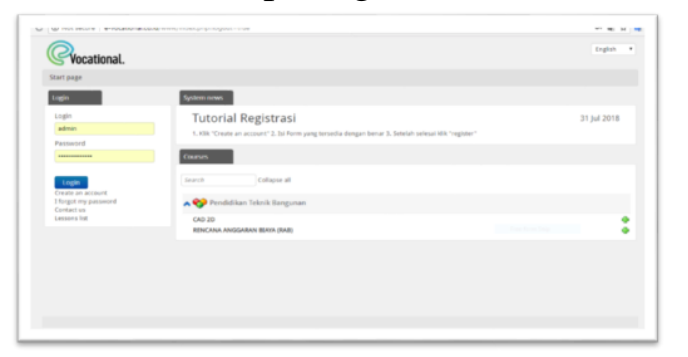

Gambar 4. Home E-Vocational 


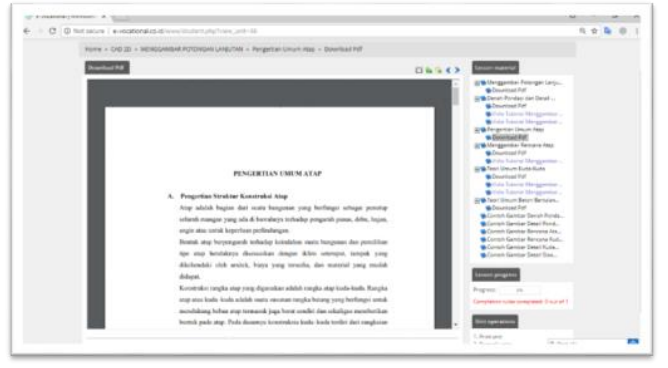

Gambar 5. Tampilan Contoh Materi teks

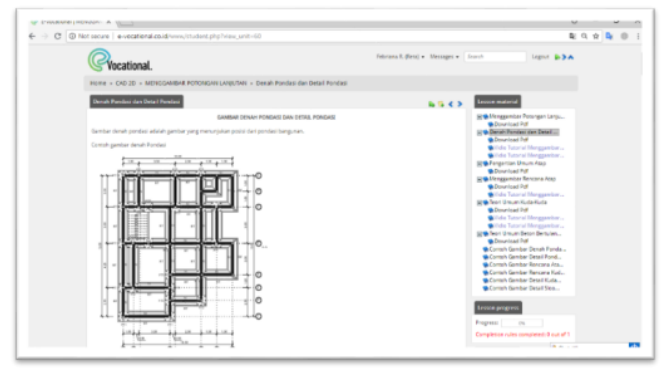

Gambar 6. Tampilan Contoh Materi Gambar

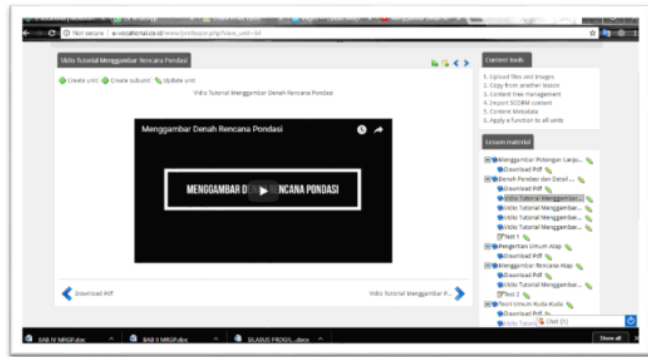

Gambar 7. Tampilan Video pada E-Vocational

c. Pembuatan Penilaian Uji Coba

Lembar penilaian uji coba berwujud validasi penilaian oleh mahasiswa sebagai pengguna media. Lembar penilaian disusun berdasarkan indikator-indikator pemilihan media pembelajaran. Indikator tersebut diantaranya karakteristik siswa, tujuan pembelajaran dan juga kemudahan dalam penggunaan media pembelajaran.

d. Validitas Tim Ahli dan Uji Coba Penggunaan.
Tahap ini memiliki tujuan untuk mengetahui Kelayakan $E$ Vocational sebagai media pembelajaran pada mata kuliah program $\mathrm{CAD} 2 \mathrm{D}$ dengan materi menggambar potongan lanjutan berdasarkan pengukuran ahli materi, ahli media, ahli pembelajaran dan 3 mahasiswa pada uji coba terbatas serta 30 mahasiswa pada ujicoba luas PTB FKIP UNS angkatan 2015 yang telah menempuh mata kuliah Program CAD 2D.

Tabel 3. Penilaian Ahli Materi

\begin{tabular}{clccc}
\hline No & Aspek & $\begin{array}{c}\text { Skor yang } \\
\text { Diperoleh }\end{array}$ & $\begin{array}{c}\text { Skor yang } \\
\text { Diharapkan }\end{array}$ & $\begin{array}{c}\text { Persentase } \\
(\%)\end{array}$ \\
\hline 1 & Pembelajaran & 26 & 30 & $\mathbf{8 7 \%}$ \\
2 & Tampilan & 27 & 35 & $77 \%$ \\
3 & Isi/materi & 32 & 35 & $91 \%$ \\
\hline & Total & $\mathbf{8 5}$ & $\mathbf{1 0 0}$ & $\mathbf{8 5 \%}$ \\
\hline
\end{tabular}

Pada tabel 3. Menunjukkan penilaian Ahli Materi sebagai berikut: pengukuran aspek pembelajaran sebesar $87 \%$, aspek tampilan sebesar 77\%, aspek isi/materi $91 \%$. Jika dirata-rata tingkat kelayakan media pembelajaran E-Vocational menjadi $85 \%$ termasuk pada kategori sangat layak.

Tabel 4. Penilaian Ahli Media

\begin{tabular}{llccc}
\hline No & \multicolumn{1}{c}{ Aspek } & $\begin{array}{c}\text { Skor yang } \\
\text { Diperoleh }\end{array}$ & $\begin{array}{c}\text { Skor yang } \\
\text { Diharapkan }\end{array}$ & $\begin{array}{c}\text { Persentase } \\
\mathbf{( \% )}\end{array}$ \\
\hline 1 & Isi/materi & 27 & 30 & $90 \%$ \\
2 & Bahasa dan gambar & 28 & 30 & $93 \%$ \\
3 & Penyajian & 45 & 50 & $90 \%$ \\
4 & Pemrograman & 40 & 40 & $100 \%$ \\
\hline \multicolumn{2}{l}{ Total } & $\mathbf{1 4 0}$ & $\mathbf{1 5 0}$ & $\mathbf{9 3 \%}$ \\
\hline
\end{tabular}

Pada tabel 4. Menunjukkan penilaian Ahli Media. Validasi penilaian oleh ahli media berisi 30 butir pertanyaan dengan indikator antara lain: aspek isi/ materi, aspek bahasa dan gambar, penyajian, 
pemrograman. Dengan presentase hasil pengukuran yaitu: isi/ materi sejumlah 90\%, Bahasa dan gambar sejumlah $93 \%$, penyajian sejumlah $90 \%$, pemrograman sejumlah $100 \%$. Jika dirata-rata tingkat kelayakan media pembelajaran E-Vocational menjadi 93\%.termasuk kategori sangat layak.

Tabel 5. Penilaian Ahli Pembelajaran

\begin{tabular}{llccc}
\hline No & \multicolumn{1}{c}{ Aspek } & $\begin{array}{c}\text { Skor yang } \\
\text { Diperoleh }\end{array}$ & $\begin{array}{c}\text { Skor yang } \\
\text { Diharapkan }\end{array}$ & $\begin{array}{c}\text { Persentase } \\
\text { (\%) }\end{array}$ \\
\hline 1 & Pembelajaran & 26 & 30 & $87 \%$ \\
2 & Tampilan & 30 & 35 & $86 \%$ \\
3 & Isi/materi & 28 & 40 & $70 \%$ \\
4 & Ketepatgunaan & 12 & 20 & $60 \%$ \\
\hline & Total & $\mathbf{9 6}$ & $\mathbf{1 2 5}$ & $\mathbf{7 7 \%}$ \\
\hline
\end{tabular}

Pada tabel 5. Menunjukkan evaluasi Ahli Pembelajaran. pengujian kelayakan ahli pembelajaran melalui validasi pengujian ahli pembelajaran berisi 25 item pertanyaan. Indikator pertanyaan diantaranya: aspek pembelajaran, aspek tampilan, aspek isi/materi, aspek ketepatgunaan. Dengan presentase hasil pengukuran yaitu: pembelajaran sejumlah $87 \%$, tampilan sejumlah $86 \%$, isi/materi sejumlah $70 \%$, ketepatgunaan sejumlah $60 \%$. Jika dirata-rata tingkat kelayakan media pembelajaran E-Vocational menjadi $77 \%$ termasuk kategori layak.

Tabel 6. Pengukuran Mahasiswa Ujicoba Terbatas

\begin{tabular}{llccc}
\hline No & \multicolumn{1}{c}{ Aspek } & $\begin{array}{r}\text { Skor yang } \\
\text { Diperoleh }\end{array}$ & $\begin{array}{c}\text { Skor yang } \\
\text { Diharapkan }\end{array}$ & $\begin{array}{c}\text { Persentase } \\
\mathbf{( \% )}\end{array}$ \\
\hline 1 & Umum & 53 & 60 & $88 \%$ \\
2 & Komunikasi Visual & 82 & 90 & $91 \%$ \\
3 & Rekayasa Perangkat & 71 & 75 & $95 \%$ \\
& Lunak & & & \\
4 & Desain Pembelajaran & 69 & 75 & $92 \%$ \\
\hline \multicolumn{2}{l}{ Total } & $\mathbf{2 7 5}$ & $\mathbf{3 0 0}$ & $\mathbf{9 2 \%}$ \\
\hline
\end{tabular}

Pada tabel 6. Menunjukkan penilaian Mahasiswa Uji Coba Terbatas. Persentase hasil penilaian uji coba terbatas sebagai berikut: aspek umum sebesar $88 \%$, komunikasi visual sebesar $91 \%$, rekayasa perangkat lunak sebesar 95\% dan desain pembelajaran sebesar 92\%. Rata-rata Uji coba terbatas didapat presentase $92 \%$. termasuk pada kategori sangat layak.

Tabel 7. Penilaian Mahasiswa Uji Coba Luas

\begin{tabular}{llccc}
\hline No & \multicolumn{1}{c}{ Aspek } & $\begin{array}{r}\text { Skor yang } \\
\text { Diperoleh }\end{array}$ & $\begin{array}{c}\text { Skor yang } \\
\text { Diharapkan }\end{array}$ & $\begin{array}{c}\text { Persentase } \\
\text { (\%) }\end{array}$ \\
\hline 1 & Umum & 510 & 600 & $85 \%$ \\
2 & Komunikasi Visual & 766 & 900 & $85 \%$ \\
3 & Rekayasa Perangkat & 629 & 750 & $84 \%$ \\
& Lunak & & & \\
4 & Desain Pembelajaran & 622 & 750 & $83 \%$ \\
\hline & Total & $\mathbf{2 5 2 7}$ & $\mathbf{3 0 0 0}$ & $\mathbf{8 4 \%}$ \\
\hline
\end{tabular}

Pada tabel 7. Menunjukkan penilaian Mahasiswa Uji Coba Luas. Presentasenya antara lain: umum senilai $85 \%$, komunikasi visual senilai $85 \%$, rekayasa perangkat lunak senilai $84 \%$ dan desain pembelajaran senilai $83 \%$. Diperoleh rata-rata senilai $84 \%$ termasuk pada kategori sangat layak.

3. Tahapan evaluasi

bagian dari tahapan evaluasi adalah model final dimana setelah medi pemebelajaran E-Vocational divalidasi penilaian oleh para ahli materi, media, dan pembelajaran kemudian diterapkan untuk pengguna/ mahasiswa pada tahap ujicoba terbatas dan ujicoba luas. Hasil akhir ini berwujud media pembelajaran E-Vocational yang siap dimanfaatkan sebagai media pada mata kuliah program CAD

$2 \mathrm{D}$. 


\section{SIMPULAN}

1. Prosedur pengembangan EVocational sebagai media pembelajaran pada mata kuliah program CAD 2D dengan materi menggambar potongan lanjutan antara lain: Studi Literatur, Pengkajian Materi, Draft Desain Model, Validasi Desain, Ujiccoba Kelompok Kecil, Evaluasi dan Perbaikan, Ujicoba Kelompok Luas, Evaluasi serta Perbaikan, Model Final

2. Kelayakan E-Vocational sebagai media pembelajaran pada mata kuliah program CAD 2D dengan materi menggambar potongan lanjutan berdassarkan validasi pengukuran para ahli materi, media, pembelajaran dan pengguna.

a. Ahli materi dengan presentase sebesar $85 \%$ termasuk kategori sangat layak.

b. Ahli media presentase sebesar 93\% termasuk kategori sangat layak.

c. Ahli pembelajaran presentase senilai $77 \%$ terhitung layak.

d. Ujicoba grup kecil berdasar tanggapan 3 mahasiswa PTB FKIP UNS angkatan 2015 diperoleh presentase sebesar 92\% terhitung sangat layak.

e. Ujicoba grup luas berdasar tanggapan 30 mahasiswa PTB FKIP UNS angkatan 2015 terhitung sangat layak.

\section{SARAN PENGGUNAAN}

1. Dibutuhkan adanya HP atau computer yang terhubung dengan internet agar dapat mengakses $E$ vocational.co.id

2. Produk penelitian yang dihasilakn ini masih terdapat kelemahan, kedepannya untuk peneliti lain yang ingin memajukan kembali $E$ Vocational dapat menggunakan skrip pengkodean sendiri atau bisa dengan membeli skrip pengkodean yang lebih baru agar media pembelajaran dapat mengikuti perkembangan jaman dan lebih interaktif.

3. Desain produk masih ada kekurangan, kedepanya untuk penelitian yang ingin mengembangkan kembali $E$ Vocational dapat membuat tampilan dan layout disain yang lebih menarik sesuai dengan perkembangan jaman serta mengikuti model yang lebih di sukai pengguna E-Vocational

\section{DAFTAR PUSTAKA}

Aqib, Z. (2013). Model-model, Media, dan Strategi Pembelajaran Kontekstual

(Inovatif). Bandung: Yrama Widya.

Indriana, D. (2011). Ragam Alat Bantu Media Pengajaran, Jogjakarta: Diva Perss.

Permendikbud No. 65 Tahun 2013 Tentang Standar Proses Pendidikan Dasar dan Menengah.

Sanaky, H.A.H. (2015). Media Pembelajaran Interaktif-Inovatif. 
Sjukur, S.B. (2012). Pengaruh Blended Learning Terhadap Motivasi Belajar dan Hasil Belajar Siswa Tingkat SMK. Jurnal Pendidikan Vokasi. Vol. 2. Nomor 3. 368-378

Sugiyono. (2017). Metode Penelitian Pendidikan Pendekatan Kuantitatif Kualitatif dan $R \& D$. Bandung: Alfabeta.

Thorne, K. (2003). Blended learning: How to integrate online and traditional learning. London. Kogan Page. 